\title{
Exergy Analysis of 1 x 135 MW Jeneponto Steam Power Plant
}

\author{
Nur Hamzah $^{1, \mathrm{a}}$, A. M. Shiddiq Yunus ${ }^{1, \mathrm{~b}}$, and Waqva Enno Al Fadiyah ${ }^{1, \mathrm{c}}$ \\ ${ }^{1}$ Mechanical Engineering Department, State Polytechnic of Ujung Pandang, Jalan Perintis Kemerdekaan KM 10 , \\ Makassar 90245, Indonesia \\ ahamzah_said@poliupg.ac.id, ${ }^{\mathrm{b}}$ shiddiq@poliupg.ac.id, ${ }^{\mathrm{c}}$ waqva1197@gmail.com
}

\begin{abstract}
Exergy analysis is application of the second law thermodynamics which provides information about large exergy, exergy efficiency, destruction, and destruction efficiency in each component of PLTU so can be reference for improvement and optimization in an effort to reduce losses and increase efficiency. The exergy value obtained from calculating mass flowrate, enthalpy, ambient temperature, and entropy. The destruction value is obtained from difference between input exergy value and exergy output. The destruction exergy value from comparison between output exergy value to input exergy value, and destruction efficiency value from comparison of destruction value to total destruction value of PLTU components. The results showed that the largest exergy occurred in boilers, namely 778.225 MW in 2018, 788.824 MW in 2019, and 796.824 MW in 2020, lowest exergy value in $\mathrm{CP}$ was $0.160 \mathrm{MW}$ in 2018, $0.176 \mathrm{MW}$ in 2019, and $0.160 \mathrm{MW}$ in 2020. The largest destruction occurred in boilers, namely 163.970 MW with destruction efficiency $79.242 \%$ in 2018 , 179.450 MW with destruction efficiency $82.111 \%$ in 2019, and 199.637 MW with destruction efficiency $83.448 \%$ in 2020, lowest exergy destruction value at $\mathrm{CP}$, namely $0.056 \mathrm{MW}$ with destruction efficiency $0.027 \%$ in 2018, 0.059 MW with destruction efficiency $0.027 \%$ in 2019 , and $0.056 \mathrm{MW}$ with destruction efficiency $0.023 \%$ in 2020 . The exergy efficiency occurred in HPH 2, amounting to $94.750 \%$ in $2018,95.187 \%$ in 2019, and $94.728 \%$ in 2020 , while lowest of exergy efficiency was in LPH 1, namely 43.637 MW in 2018, 33.512 MW in 2019, and 38.764 MW in 2020.
\end{abstract}

Keywords: Exergy, destruction, exergy efficiency, destruction efficiency.

\section{Introduction}

The power plant that uses coal as fuel is a Steam Power Plant (PLTU). Steam Power Plant is a power plant that uses steam power as the main engine of a turbine to produce electricity. One of the Steam Power Plants (PLTU) located in South Sulawesi is the Jeneponto Steam Power Plant (PLTU) which is managed by PT. Bosowa Energi. Located in Punagaya Village, Bangkala District, Jeneponto Regency which has 4 generating units with a production capacity of 2 $\times 125$
MW and $2 \times 135 \mathrm{MW}$. The Jeneponto PLTU for $2 \times 135$ MW units began operating in 2017. With an operating period of 3 years, there will certainly be a decline in performance, causing the efficiency of the PLTU to decrease. Efficiency is an indicator and the most important aspect to pay attention to in measuring the overall performance of the energy generation system because it relates to managing input and output relationships regarding the optimal allocation of available production factors to be able to produce maximum output [1]. Considering that the increase in the efficiency of power plant performance is an important factor that needs to be evaluated, it is necessary to carry out an analysis to identify the destruction of each component. In general, the performance of thermal power plants is evaluated through energy analysis which is the application of the first law of thermodynamics but this analysis only provides information about the amount or quantity of energy and does not indicate whether the energy change from one form to another is perfect or not. overcoming the limitations of the first law of thermodynamics a more complete evaluation can be carried out by using exergy analysis which is the application of the second law of thermodynamics relating to energy quality, its value is influenced by the environment, and is useful in the design, evaluation, optimization and improvement of thermal power plants [2, 3].

Exergy is the working potential of maximum energy or energy that can be converted from a system to work when the system interacts with its environment and the system reaches a thermodynamic balance with its environment (dead state) [3].

There have been many researches on exergy analysis by researchers. Ahmadi and Toghraie in Ref [4] investigated steam cycle of Shahid Montazeri Power Plant of Isfahan with individual unit capacity of 
200 MW. All cycle equipment have been analyzed individually using mass, energy, and exergy balance equations. EES (Engineering Equation Solver) software is used to analyze of energy efficiency, exergy efficiency, and irreversibility. Values and ratios regarding heat drop and exergy loss have been presented for each equipment in individual tables. They concluded that $69.8 \%$ of the total lost energy in the cycle occurs in the condenser as the main equipment wasting energy, while exergy analysis introduces the boiler as the main equipment wasting exergy where $85.66 \%$ of the total exergy entering the cycle is lost.

Karyadi et al. [5] presented energy and exergy analysis to identify the decline in performance at PLTU Banten 3 Lontar both in location and magnitude. The identification of performance degradation for each component is carried out through the calculation of exergy loss. Based on the results of the analysis, it identifies that the boiler has the highest level of losses and for turbines, condensers, and dearators are components that are in usable condition, while for other components are still within safe limits for use. The same thing was also studied by [2] using the second law analysis of thermodynamics to explore the performance of the components and to get the location and magnitude of the exergy losses that occurred in each component.

As with previous studies, this study also obtained the same analysis results, namely that the boiler was identified as having the largest exergy destruction compared to other components. Ref. [6] also used exergy analysis to determine how much exergy efficiency occurs in each major component of the PLTU system. This study shows that the boiler experiences the greatest exergy destruction among the other main components. Ref. [7] used thermodynamic calculations to determine the amount of energy losses as well as exergy losses. However, this research looks different from previous research where the parameter data is inputted into Cycle Tempo so that it makes it easier to obtain results in the form of pressure, mass flow rate, enthalpy, entropy, and vapor quality. Apart from that, this research also conducts analysis and evaluation of thermoeconomics and exergoeconomics to find out which main components need attention for improvement.
Based on these basic ideas and views, a study entitled "Exergy Analysis at Steam Power Plant (PLTU) Jeneponto $1 \times 135 \mathrm{MW}$ " was conducted with the hope that the results obtained can be a reference for future improvement and optimization.

\section{Research Methodology}

Research was conducted at PT. Bosowa EnergySteam Power Plant Jeneponto. The flowchart diagram of the research stages is shown in Figure 1.

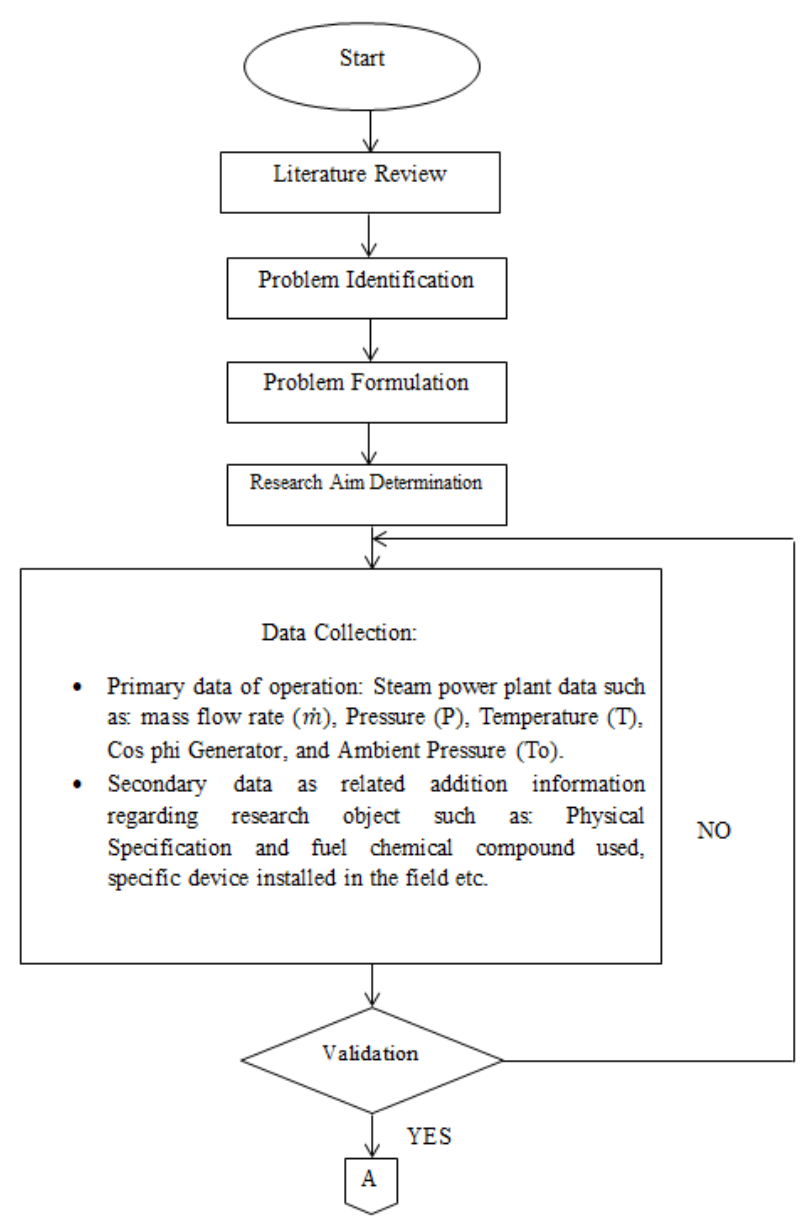




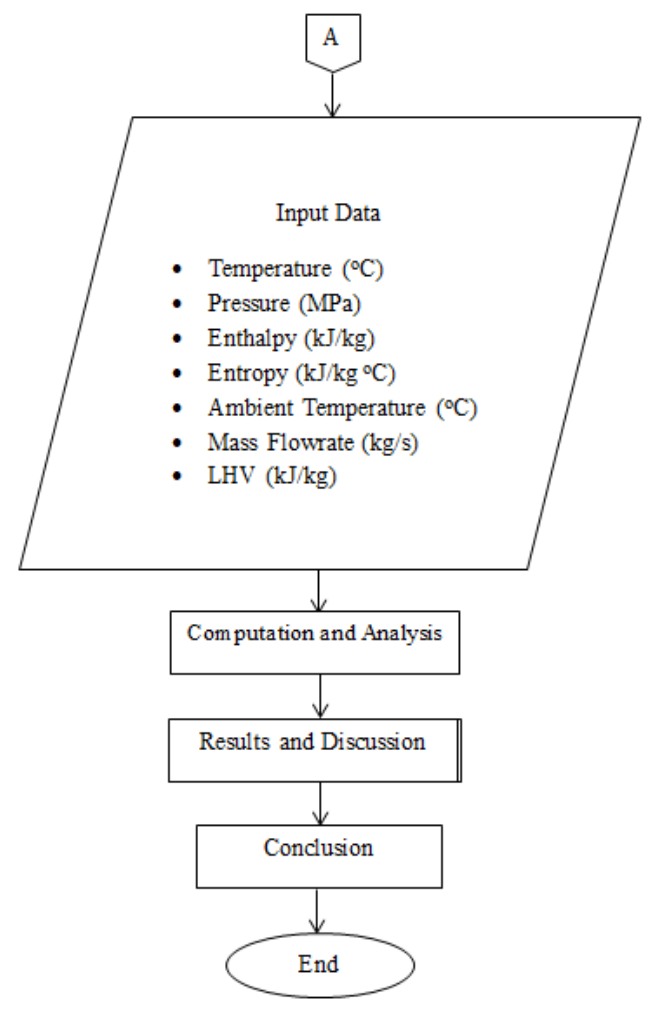

Figure 1. Flowchart of research stage

\section{Result and Discussion}

Figures 2 and 3 show the magnitude of exergy that occurred in each component from 2018 to 2020. The graph shows that the largest exergy value occurred in boilers, which in the last 3 years has increased, namely $778,225 \mathrm{MW}$ in 2018, 788,824 MW in 2019, and 796,807 MW in 2020. The lowest exergy value occurred in CP, namely in 2018 of $0.160 \mathrm{MW}, 0.176$ MW in 2019, and 0.160 MW in 2020.

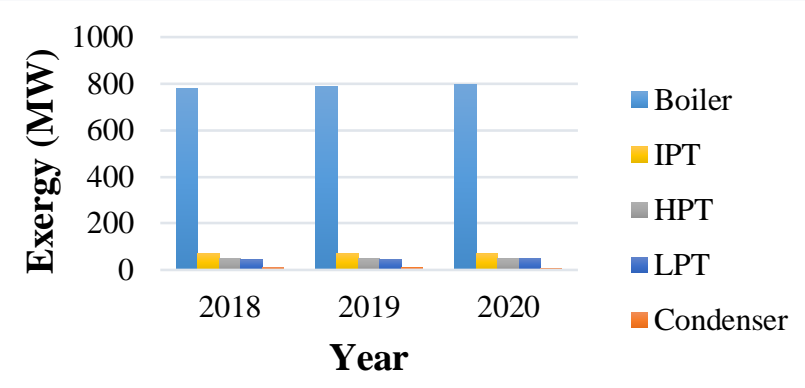

Figure 2. Graph of 137 MW Load Exergy on a Boiler, Intermediate Pressure Turbine (IPT), High Pressure Turbine (HPT), Low Pressure Turbine (LPT), and Condenser.

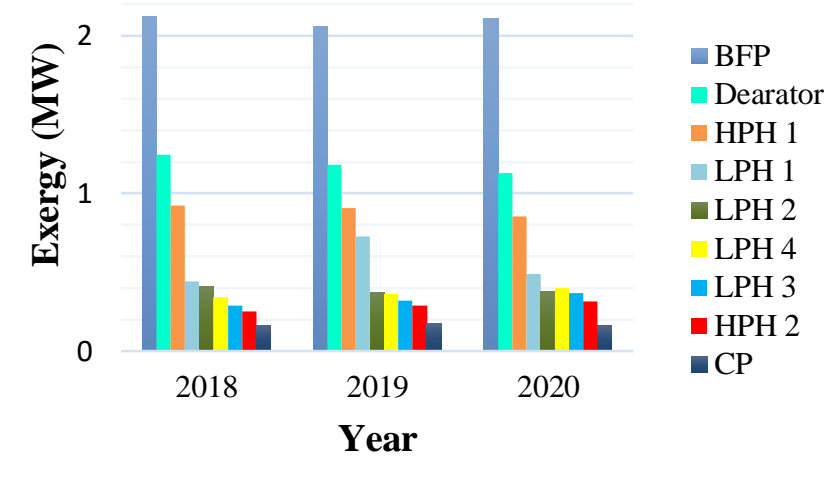

Figure 3. Graph of 137 MW Load Exergy on Boiler Feed Pump (BFP), Deaerator, High Pressure Heater (HPH), Low Pressure Heater (LPH), and Condensate Pump (CP)

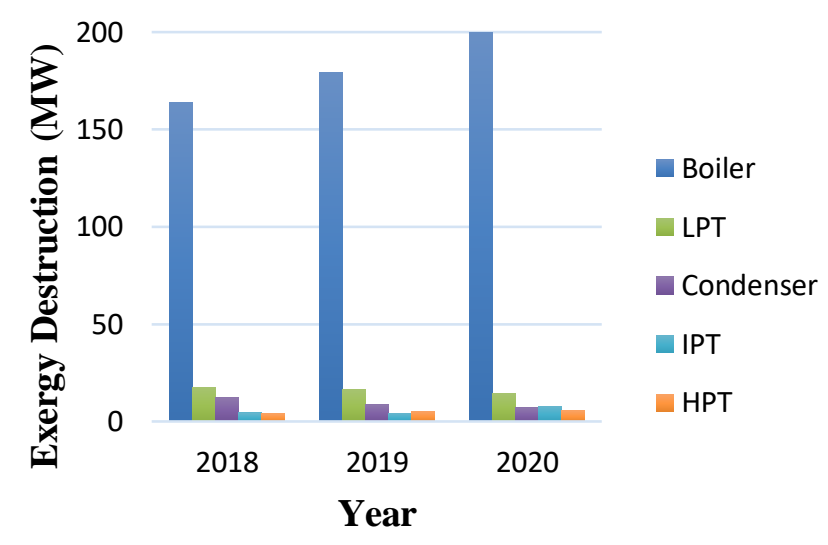

Figure 4. Graph of 137 MW Load Exergy Digestion on Boilers, Intermediate Pressure Turbine (IPT), High Pressure Turbine (HPT), Low Pressure Turbine (LPT), and Condenser.

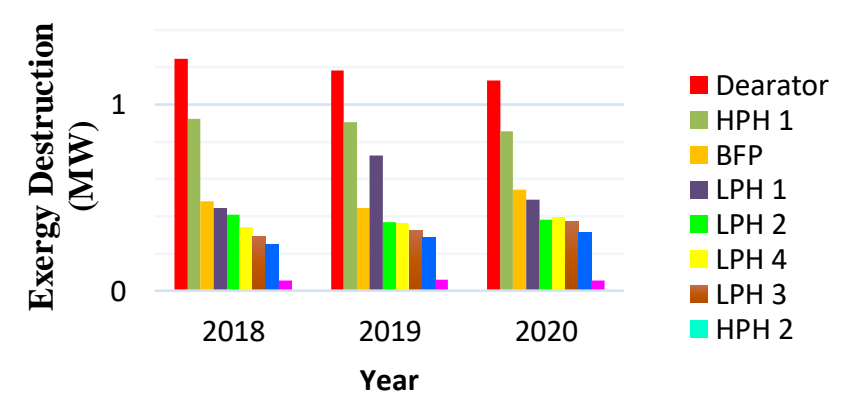

Figure 5. Graph of 137 MW Load Exergy Digestion on Boiler Feed Pump (BFP), Deaerator, High Pressure Heater (HPH), Low Pressure Heater (LPH), and Condensate Pump (CP). 
Figure 4 and 5 show the magnitude of exergy destruction that occurred in each component from 2018 to 2020 . The graph shows that the largest exergy destruction or destruction value occurred in boilers, the magnitude of which during the last 3 years has increased, namely 163,970 MW in 2018, 179,450 MW in 2019, and 199,637 MW in 2020. The lowest exergy destruction value occurred in CP, namely $0.056 \mathrm{MW}$ in 2018, 0.059 MW in 2019, and 0.056 MW in 2020. The largest exergy destruction occurred in the main components due to by combustion reactions, heat transfer, and friction. The combustion process that occurs in the boiler results in irreversibility to chemical reactions which results in the boiler being the largest source of destruction. This is in line with what was stated by [8] when using exergy analysis, the greatest reduction occurs in the boiler, whereas if using energy analysis or the first law of thermodynamics it will show that the greatest destruction occurs in the condenser.

The exergy destruction that occurs in the turbine is caused by the friction factor. If there is a friction on a surface it will make the component lose some of its structure, this structural loss cannot return to its original shape.

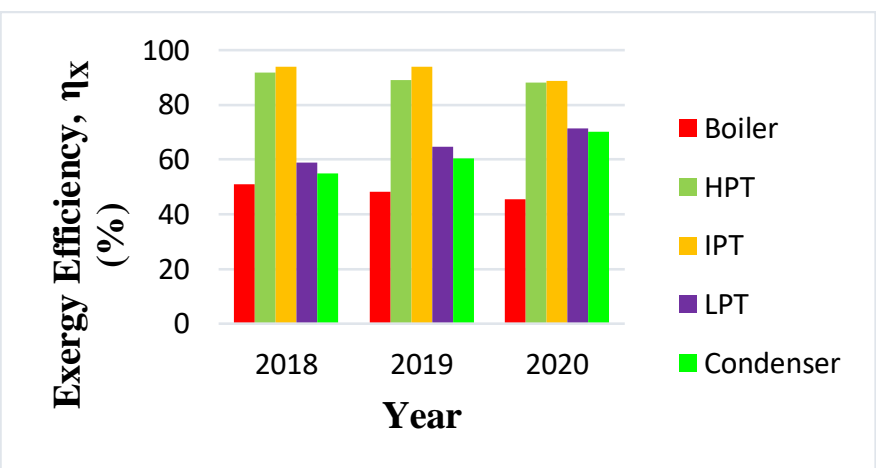

Figure 6 Graph of 137 MW Load Exergy Efficiency in Boilers, Intermediate Pressure Turbine (IPT), High Pressure Turbine (HPT), Low Pressure Turbine (LPT), and Condenser

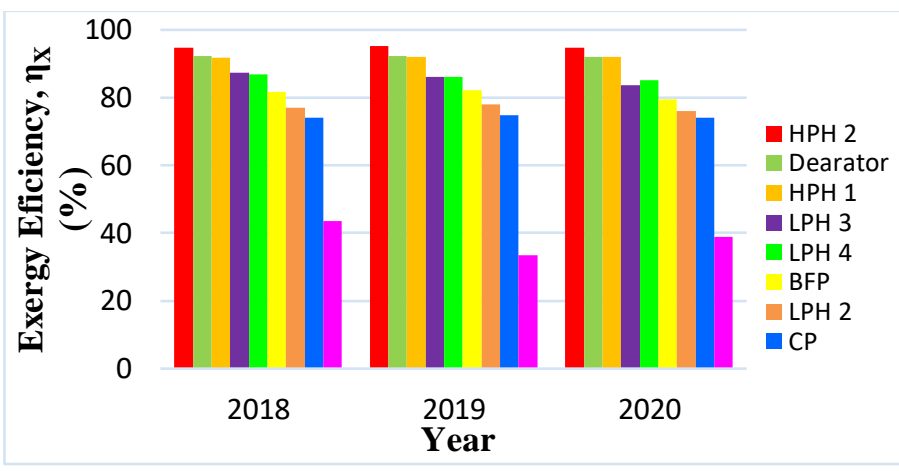

Figure 7. Graph of 137 MW Load Exergy Digestion on Boiler Feed Pump (BFP), Deaerator, High Pressure Heater (HPH), Low Pressure Heater (LPH), and Condensate Pump (CP).

Figure 6 and 7 show the magnitude of exergy efficiency that occurred in each component from 2018 to 2020. This graph shows that in a three-year period, the exergy efficiency has decreased not too far. The largest exergy efficiency occurred in HPH 2, namely $94,750 \%$ in $2018,95,187 \%$ in 2019 , and $94,728 \%$ in 2020. Meanwhile, the lowest exergy efficiency occurred in LPH 1, namely 43,637 MW in 2018, $33,512 \mathrm{MW}$ in 2019, and 38,764 MW in 2020. The performance of the components in terms of exergy efficiency. This provides information that components that have low exergy efficiency have poor performance and need attention from a maintenance perspective.

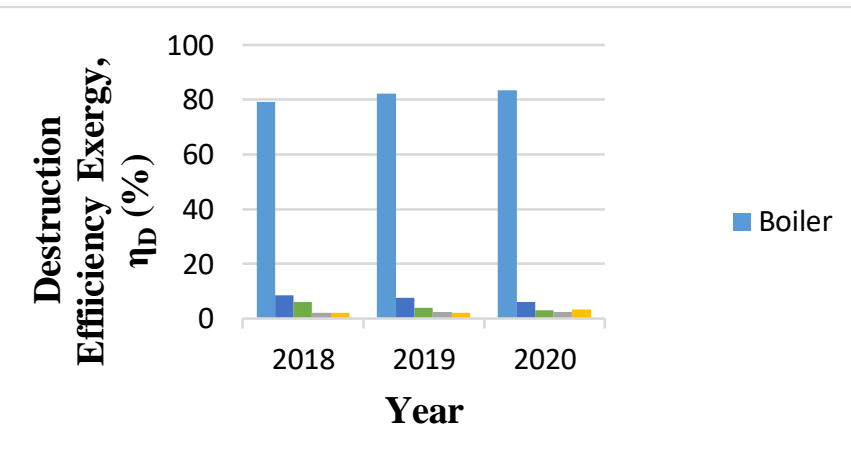

Figure 8. Graph of 137 MW Load Exergy Digestion Efficiency in Boilers, Intermediate Pressure Turbine (IPT), High Pressure Turbine (HPT), Low Pressure Turbine (LPT), and Condenser. 


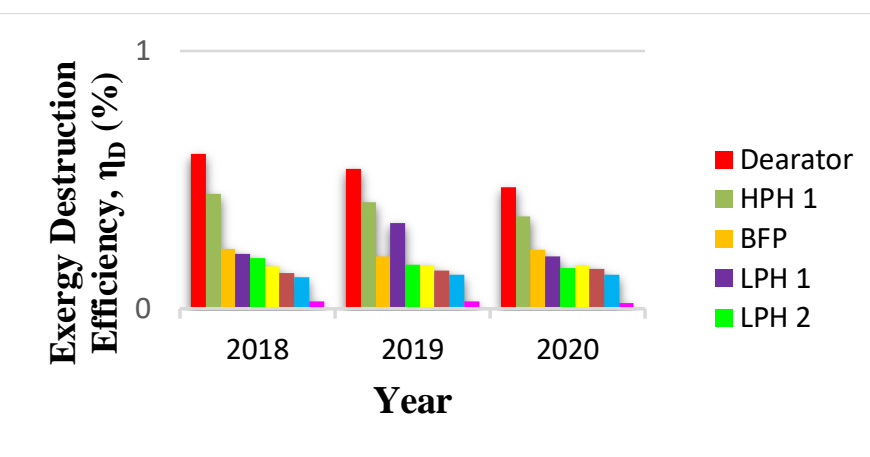

Figure 9. Graph of 137 MW Load Exergy Digestion Efficiency in Boiler Feed Pump (BFP), Deaerator, High Pressure Heater (HPH), Low Pressure Heater (LPH), and Condensate Pump (CP).

Figure 8 and 9 show the large exergy destruction efficiency that occurred in each component from 2018 to 2020. The graph shows that the boiler experienced the largest exergy destruction efficiency or exergy destruction, namely $79,242 \%$ in $2018,82,111 \%$ in 2019 , and $83,448 \%$ in 2020. Meanwhile, the lowest digestion efficiency occurred in CP where $0.027 \%$ in $2018,0.027 \%$ in 2019 , and $0.023 \%$ in 2020 . This shows that the boiler experienced the greatest exergy destruction efficiency, so it is necessary to take proactive steps to minimize losses experienced by the boiler.

\section{Conclusion}

The conclusions from the discussion are:

1. Exergy analysis with the calculation of exergy destruction can identify a decrease in performance in the form of value and location of components in the PLTU.

2. The largest destruction occurred in boilers of $163,970 \mathrm{MW}$ in $2018,179,450 \mathrm{MW}$ in 2019 , and $199,637 \mathrm{MW}$ in 2020 with a digestion efficiency of $79,242 \%$ in $2018,82,111 \%$ in 2019 , and $83,448 \%$ in 2020 of the total destruction rate that happens to the system.

\section{References}

[1] Musa, et al. 2018. Exergy Analysis On Thermal Power Plant PT. Makassar Tene Using Cycle-Tempo 5. SINERGI Vol. 2 No. 2, pp. 178-190.

[2] Phanama, et al. 2019. Analisa Eksergi Sistem Pembangkit Listrik Tenaga Uap (PLTU) di PT. Indonesia Power Unit Jasa Pembangkit Sanggau. (Exergy Analysis of Steam Power Plant of PT Indonesia Power Sanggau), Jurnal Teknologi Rekayasa Teknik Mesin (JTRAIN), Vol.1 No.1.

[3] Cengel, Yunus A and Michael A. Boles. 2004. Thermodynamic An Engineering Approach. 5th McGraw-Hill Science/Engineering/Math. New York. (Online),

(https://www.engineeringbookpdf.com), Accessed, 23 January 2020.

[4] G.R. Ahmadi and D. Toghraie. 2016. Energy analysis of Montazeri steam power plant in Iran, Renewable and Sustainable Energy Reviews, (56), pp. 454-463.

[5] Karyadi, et al. 2016. Analisa Energi dan Eksergi Pembangkit Listrik Tenaga Uap Banten 3 Lontar. Seminar Nasional Cendakiawan, (Energy and Exergy Analysis of Steam Power Plant Banten 3 Lontara), 4: 3.1-3.9, (http://www.trijurnal.lemit.trisakti.ac.id).

[6] Anwar, et al. 2013. Analisis Eksergi pada Sistem Pembangkit Daya Tenaga Uap (PLTU) Palu (Exergy Analysis of Steam Power Plant Palu). Proceeding Seminar Nasional Tahunan Teknik Mesin XII (SNTTM XII), 7: 314-320.

[7] Hetharia, Marlon and Yolanda J. Lewarissa. 2018. Analisis Energi pada Perencanaan Pembangkit Listrik Tenaga Uap (PLTU) dengan Cycle-Tempo. (Energy Analysis of Steam Power Plant with Cycle-Tempo), Vol. 2, No. 1, pp. 1-8.

[8] Aljundi Isam H. 2009. Energy and Exergy Analysis of a Steam Power Plant In Jordan. Applied Thermal Engineering, XI (29): 324-328. 